\title{
Calcium Sensing Receptor Regulating Smooth Muscle Cells Proliferation Through Initiating Cystathionine-Gamma-Lyase/ Hydrogen Sulfide Pathway in Diabetic Rat
}

\author{
Xin Zhonga,c Yuwen Wang ${ }^{\mathrm{b}}$ Jichao Wu Aili Sun $^{\mathrm{a}}$ Fan Yang ${ }^{\mathrm{a}}$ Dan Zheng ${ }^{\mathrm{a}}$

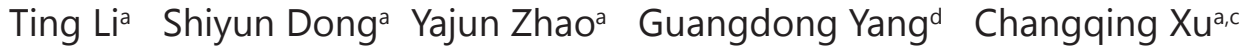 \\ Dianjun Sune Fanghao Lu ${ }^{\mathrm{a}}$ Weihua Zhang ${ }^{\mathrm{a}, \mathrm{c}}$

\begin{abstract}
aDepartment of Pathophysiology, Harbin Medical University, Harbin, bepartment of Clinical Key Laboratory of Heilongjiang Province, Harbin Medical University, Harbin, China; ${ }^{\mathrm{d} D e p a r t m e n t}$ of Biology and school of kinesiology, Lakehead University, Thunder Bay, Ontario, Canada; eCenter for Endemic Disease Control, Chinese Center for Disease Control and Prevention, Harbin Medical University, Harbin, China
\end{abstract} \\ Laboratory, The second Affiliated Hospital of Harbin Medical University, Harbin, cBio-pharmaceutical
}

\section{Key Words}

Calcium sensing receptor • Smooth muscle cells • Proliferation • Hydrogen sulfide • Diabetic rat

\begin{abstract}
Aims: Hydrogen sulfide $\left(\mathrm{H}_{2} \mathrm{~S}\right)$ inhibits the proliferation of vascular smooth muscle cells (VSMCs). However, how cystathionine-gamma-lyase (CSE), a major enzyme that produces $\mathrm{H}_{2} \mathrm{~S}$, is regulated remains unknown. Whether calcium-sensing receptor (CaSR) inhibits the proliferation of VSMCs by regulating the endogenous $\mathrm{CSE} / \mathrm{H}_{2} \mathrm{~S}$ pathway in diabetic rat has not been previously investigated. Methods and Results: The morphological and ultrastructure alterations were tested by transmission electron microscopy, changes in the $\mathrm{H}_{2} \mathrm{~S}$ concentration and the relaxation of the mesenteric secondary artery loop of diabetic rats were determined by Multiskan spectrum microplate spectrophotometer and isometric force transducer. Additionally, the expression levels of CaSR, CSE and Cyclin D1 in the mesenteric arteries of rats were examined by western blotting. The intracellular calcium concentration, the expression of p-CaMK II (phospho-calmodulin kinases II), CSE activity, the concentration of endogenous $\mathrm{H}_{2} \mathrm{~S}$ and the proliferation of cultured VSMCs from rat thoracic aortas were measured by using confocal microscope, western blotting, microplate spectrophotometer, MTT and BrdU, respectively. The VSMC layer thickened, the $\mathrm{H}_{2} \mathrm{~S}$ concentration dropped, the relaxation of the mesenteric secondary artery rings weakened, and the expression of CaSR
\end{abstract}

X. Zhong and Y. Wang contributed equally.

\begin{tabular}{ll}
\hline Fanghao Lu & Department of Pathophysiology, Harbin Medical University, Harbin 150086, (China) \\
and Weihua Zhang & Tel. +86451 86699587 Fax +86 45186674548 \\
& E-Mail zhangwh116@126.com, E-Mail lufanghao1973@126.com
\end{tabular}




\section{Cellular Physiology Cell Physiol Biochem 2015;35:1582-1598 \\ \begin{tabular}{l|l} 
and Biochemistry $10.1159 / 000373973$ & $\begin{array}{l}\text { DOblished online: March 18, } 2015 \\
\text { Pul } 2015 \text { S. Karger AG, Basel } \\
\text { www.karger.com/cpb }\end{array}$ \\
\hline
\end{tabular}}

and CSE decreased whereas the expression of Cyclin D1 increased in diabetic rats compared with the control group. The $\left[\mathrm{Ca}^{2+}\right]_{i}$ of VSMCs increased upon treatment with CaSR agonists (10 $\mu \mathrm{M}$ Calindol and $2.5 \mathrm{mM} \mathrm{CaCl}_{2}$ ), while it decreased upon administration of calhex231, U73122 and 2-APB. The expression of p-CaMK II and CSE increased upon treatment with CaSR agonists in VSMCs. CSE activity and the endogenous $\mathrm{H}_{2} \mathrm{~S}$ concentration decreased in response to high glucose, while it increased with treatment of CaSR agonists. The proliferation rate increased in response to high glucose, and CaSR agonists or NaHS significantly reversed the proliferation of VSMCs caused by high glucose. Conclusions: Our results demonstrated that CaSR regulated the endogenous $\mathrm{CSE} / \mathrm{H}_{2} \mathrm{~S}$ pathway to inhibit the proliferation of VSMCs in both diabetic and high glucose models.

Copyright (C) 2015 S. Karger AG, Basel

\section{Introduction}

Diabetes increases the risk of cardiovascular morbidity and mortality by promoting cardiovascular injury, which is a major cause of death and disability in patients [1]. During vascular injury, vascular smooth muscle cell proliferation is a critical factor and a noted characteristic. Some studies have suggested that oxidative stress [2] and growth factors $[3,4]$ are involved in the proliferation of VSMCs in diabetes models. Recent studies have suggested that vasodilators play a major role in modulating the proliferation of VSMCs in diabetic models [5].

Hydrogen sulfide $\left(\mathrm{H}_{2} \mathrm{~S}\right)$ is the third member of the gaseous transmitter family. It is a strong reducing agent $[6,7]$ and vasodilator [8] and is endogenously synthesized from L-cysteine. In mammalian cardiovascular tissues, the biosynthesis of $\mathrm{H}_{2} \mathrm{~S}$ is mainly catalyzed by cystathionine-gamma-lyase (CSE). Recent studies have shown that $\mathrm{H}_{2} \mathrm{~S}$ is involved in vasorelaxation [8], cardioprotection [9] and the inhibition of proliferation of VSMCs [10]. A deficiency in the $\mathrm{CSE} / \mathrm{H}_{2} \mathrm{~S}$ pathway plays an important role in the development of certain cardiovascular diseases, such as spontaneous hypertension, atherosclerosis and heart failure [11-13]. However, whether $\mathrm{H}_{2} \mathrm{~S}$ protects the periphery vasculature against diabetes-induced injury remains unclear.

The calcium-sensing receptor (CaSR) belongs to the transmembrane G-protein coupled receptor family. Extracellular calcium binds CaSR to cause phosphatidylinositol biphosphate ( $\mathrm{PIP}_{2}$ ) to be cleaved into the secondary messengers diacylglycerol (DAG) and inositol 1,4,5-trisphoshpate (IP ${ }_{3}$ ) through the PLC (phospholipase C) pathway. IP ${ }_{3}$ binds the $\mathrm{IP}_{3}$ receptor on the sarcoplasmic reticulum, which causes calcium to be released and thus increases the calcium concentration in the cytoplasm $[14,15]$. Some evidence suggests that a functional CaSR is expressed in VSMCs [16]. Some studies also confirmed that a positive modulator of CaSR induces the relaxation of rat isolated small mesenteric arteries $[17,18]$. A recent study found that increasing the $\left[\mathrm{Ca}^{2+}\right]_{\mathrm{i}}$ increases endogenous $\mathrm{H}_{2} \mathrm{~S}$ production in smooth muscle cells [19].

The role of $\mathrm{H}_{2} \mathrm{~S}$ in inhibiting the proliferation of VSMCs has been investigated previously [10]. However, the effects of the CSE/ $\mathrm{H}_{2} \mathrm{~S}$ pathway on SMC proliferation have not been characterized, and identifying an interaction between CaSR and the $\mathrm{CSE} / \mathrm{H}_{2} \mathrm{~S}$ pathway may uncover the mechanism of endogenous $\mathrm{H}_{2} \mathrm{~S}$ production.

In the present study, we determined that the reduction of $\mathrm{H}_{2} \mathrm{~S}$ production in a STZinduced diabetic rat model stimulated SMC proliferation. CaSR could influence CSE activity and $\mathrm{H}_{2} \mathrm{~S}$ production and arrest the progression of diabetic vascular injury.

\section{Materials and Methods}

Animals

Male Wistar rats (200-250 g) were obtained from the Experimental Animal Center of Harbin Medical University (Harbin, People's Republic of China). All animal experimental protocols complied with the 'Guide 


\section{Cellular Physiology Cell Physiol Biochem 2015;35:1582-1598 \begin{tabular}{l|l} 
and Biochemistry Published online: March 18, 2015 & $\begin{array}{l}\text { C 2015 S. Karger AG, Basel } \\
\text { www.karger.com/cpb }\end{array}$ \\
\hline
\end{tabular} \\ Zhong et al.: CaSR Regulating VSMCs Proliferation}

for the Care and Use of Laboratory Animals' published by the United States National Institutes of Health. The study was approved by the Institutional Animal Research Committee of Harbin Medical University. All animals were housed at the animal care facility of Harbin Medical University at $25{ }^{\circ} \mathrm{C}$ with $12 / 12$-h light/ dark cycles and allowed free access to normal rat chow and water throughout the study period. Rats were randomly assigned to different treatment groups.

\section{Experimental groups}

Diabetes was induced by streptozotocin (STZ) through intraperitoneal as previously reported [20]. Diabetes was induced by tail vein injection of STZ (streptozotocin, $50 \mathrm{mg} / \mathrm{kg}$ ) dissolved in $0.1 \mathrm{M}$ citrate buffer ( $\mathrm{pH} 4.5)$, whereas the control group were injected citrate buffer alone by the same route. Glucose $(10$ $\%$ ) was added into the drinking water of STZ-treated rats during the first $24 \mathrm{~h}$ to reduce hypoglycemic phase following STZ injection. Blood glucose levels of the rats were measured using blood glucose test strips after $72 \mathrm{~h}$ of STZ injection, and blood glucose levels over $16.7 \mathrm{mM}$ were accepted as diabetes. Rats were divided into 4, 8, and 12 weeks diabetes groups and diabetes + NaHS treatment groups, the daily administration of $80 \mu \mathrm{M}$ NaHS intraperitoneal injection in the NaHS treatment group rats. Measurement of blood glucose was repeated after 2 weeks of treatment in each group.

\section{Morphological changes in the mesenteric secondary arteries of rats}

Ultrastructural alterations of mesenteric secondary arteries of rats were detected by transmission electron microscopy (TEM). Samples were taken at the mesenteric secondary arteries in five rats from each group. Samples for TEM were cut into pieces less than $1 \mathrm{~mm}^{3}$ and fixed in $2.5 \%$ glutaraldehyde in $0.1 \mathrm{M}$ sodium cacodylate buffer ( $\mathrm{pH} 7.4$ ) for $4 \mathrm{~h}$. Tissues were post-fixed in $1 \%$ osmium tetroxide in $1 \% \mathrm{~K}_{4} \mathrm{Fe}(\mathrm{CN})_{6}$ buffered with $0.1 \mathrm{M}$ sodium cacodylate, dehydrated through graded concentrations of ethanol and propylene oxide and subsequently embedded in Epon 812. Ultrathin sections were cut from blocks and mounted on copper grids. Then, the grids were counterstained with lead citrate and uranyl acetate. Photomicrographs were obtained using Zeiss Axiophot microscopes.

\section{Histological Examination}

Some sections of the mesenteric secondary artery tissue were fixed in $4 \%$ paraformaldehyde in PBS ( $\mathrm{pH}$ 7.4). The fixed mesenteric secondary artery tissues were embedded in paraffin and cut into $4 \mu \mathrm{m}$-thick sections. The sections were then stained with Masson trichrome stain to reveal histological changes and areas of interstitial fibrosis [21].

\section{The changes on the relaxation rate of rat mesenteric secondary artery rings}

The rat mesenteric secondary arteries were isolated, and rings of approximately 2-3 mm in length were prepared. Subsequently, the rings were mounted under a resting tension of $1.0 \mathrm{~g}$ in organ baths filled with Krebs-Henseleit solution. Tissues were equilibrated for $1.5 \mathrm{~h}$ and washed by Krebs-Henseleit solution every $15 \mathrm{~min}$ before each experimental procedure. Isometric changes in tension were recorded with an isometric force transducer (MAY95-transducer data acquisition system). The composition of the KrebsHenseleit solution (in $\mathrm{mM}$ ) was $\mathrm{NaCl}, 113 ; \mathrm{KCl}, 4.7 ; \mathrm{MgSO}_{4}, 1.2 ; \mathrm{CaCl}_{2}, 2.5 ; \mathrm{KH}_{2} \mathrm{PO}_{4}, 1.2 ; \mathrm{NaHCO}_{3}, 25.0$; and glucose, 11.6 and this was gassed with $95 \% \mathrm{O}_{2}-5 \% \mathrm{CO}_{2}$ at $37{ }^{\circ} \mathrm{C}$ and $\mathrm{pH}$ 7.4.

Reagents aqueous solution was introduced directly into the organ bath by an automated pipette. At the beginning of each experiment, $\mathrm{KCl}(60 \mathrm{mM})$-induced contractions were elicited in mesenteric arteries isolated from different groups of rats. After a $30 \mathrm{~min}$ washout period, the arteries were precontracted by $1 \mathrm{nM}$ phenylephrine and then the relaxation response to reagents (Calindol, $5 \mu \mathrm{M}$ or NaHS, $60 \mu \mathrm{M}$ ) were evaluated by cumulative addition to the organ bath. The functionality of the endothelium was also determined after obtaining the reagents induced relaxation response. For this purpose, after an hour of washout period, the arteries were again precontracted by phenylephrine $(1 \mathrm{nM})$, and then the concentration-dependent relaxation response $(<70 \%)$ to acetylcholine $(0.1 \mathrm{mM})$ was elicited by cumulative addition to the organ bath.

Vascular smooth muscle cells of rat thoracic aorta (A7r5) culture

Vascular smooth muscle cells of rat thoracic aorta (A7r5) were maintained in DMEM containing 10 $\%$ fetal bovine serum (FBS) (Gibco-BRL, Life Technologies, Gaithersburg, MD), penicillin (100 IU/ml), and 


\section{Cellular Physiology Cell Physiol Biochem 2015;35:1582-1598

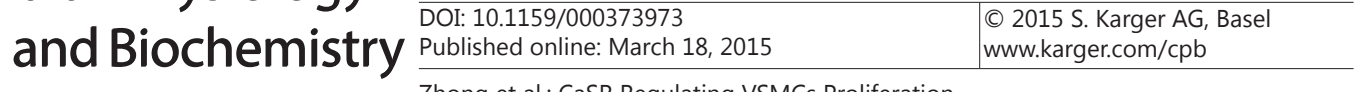

streptomycin $(100 \mu \mathrm{g} / \mathrm{ml})$ at $37^{\circ} \mathrm{C}$ in a humidified chamber containing $5 \% \mathrm{CO}_{2}$ incubator. The experiments were performed when the cells reached $80-90 \%$ confluence. In all studies, cells were incubated in the low glucose $(5.56 \mathrm{mM})$ medium. In certain selective experiments, cells were subsequently incubated in the high glucose (25 mM) medium for $72 \mathrm{~h}$.

\section{Measurement of $\left[\mathrm{Ca}^{2+}{ }_{i}\right.$ with Fluo-4/AM}

The VSMCs were placed onto coverslips, which were covered in 12-well culture plates. After $72 \mathrm{~h}$ at 37 ${ }^{\circ} \mathrm{C}$, the VSMCs were washed with PBS and incubated with $5 \mu \mathrm{M}$ Fluo-4/AM for $30 \mathrm{~min}$ at $37^{\circ} \mathrm{C}$ in the dark. The cells were rinsed three times with Tyrode's solution to remove the remaining dye. During experiment, FI (fluorescence intensity) of fluo-4/AM in VSMCs was recorded using a laser-scanning confocal microscope (Olympus, Japan) at an excitation wavelength of $488 \mathrm{~nm}$ and an emission wavelength of $530 \mathrm{~nm}$.

In positive and negative group, cells were exposed to CaSR agonists (Calindol, $2 \mu \mathrm{M}$, or $\mathrm{CaCl}_{2}, 2.5$ $\mathrm{mM})$ and BAPTA (5 $\mu \mathrm{M}$, calcium chelator) recorded for $330 \mathrm{~s}$ at $3 \mathrm{~s}$ intervals. In Calindol experiments, the VSMCs preincubated with specific inhibitor, U73122 (10 $\mu \mathrm{M}$, PLC-specific inhibitor), Calhex231 (3 $\mu \mathrm{M}$, CaSR-specific inhibitor), 2-APB (75 $\mu \mathrm{M}, \mathrm{IP}_{3}$ receptor inhibitor) and TG (10 $\mu \mathrm{M}, \mathrm{Ca}^{2+}$-ATP inhibitor) for 20 min before Calindol challenge. In $\mathrm{CaCl}_{2}$ experiments, preincubated with $\mathrm{NiCl}_{2}\left(10 \mathrm{mM}, \mathrm{Na}^{+}-\mathrm{Ca}^{2+}\right.$ exchanger inhibitor) and $\mathrm{CdCl}_{2}\left(0.2 \mathrm{mM}\right.$, L-type $\mathrm{Ca}^{2+}$ channel inhibitor) $30 \mathrm{~min}$ before the procedure. Image analysis was performed off-line using Fluoview-FV300 (Olympus, Japan) to select cell regions from which FI was extracted, and further analysis was conducted with Excel (Microsoft) and Origin Version 7.5 software (OriginLab Corporation). $\left[\mathrm{Ca}^{2+}\right]_{i}$ changes were expressed as fluorescence intensity representing FI and normalized to initial fluorescence intensity.

\section{Measurement of $\mathrm{H}_{2} \mathrm{~S}$ production}

$\mathrm{H}_{2} \mathrm{~S}$ production rate was measured as described previously [22]. Briefly, after different treatments, the cells were collected and homogenized in $50 \mathrm{mM}$ ice-cold potassium phosphate buffer (pH 6.8). The flasks containing reaction mixture $(100 \mathrm{mM}$ potassium phosphate buffer, $10 \mathrm{mM}$ L-cysteine, $2 \mathrm{mM}$ pyridoxal $5^{\prime}$-phosphate and $10 \%(\mathrm{w} / \mathrm{v}$ ) cell homogenates) and center wells containing $0.5 \mathrm{ml} 1 \%$ zinc acetate and a piece of filter paper were flushed with $\mathrm{N}_{2}$ and incubated at $37^{\circ} \mathrm{C}$ for $90 \mathrm{~min}$. The reaction was stopped by adding $0.5 \mathrm{ml}$ of $50 \%$ trichloroacetic acid, and the flasks were incubated at $37^{\circ} \mathrm{C}$ for another $60 \mathrm{~min}$. The contents of the center wells were transferred to test tubes each containing $3.5 \mathrm{ml}$ of water, $0.5 \mathrm{ml}$ of $20 \mathrm{mM}$ $N$,Ndimethyl- $p$-phenylenediamine sulfate in $7.2 \mathrm{M} \mathrm{HCl}$ and $0.5 \mathrm{ml} 30 \mathrm{mM} \mathrm{FeCl}_{3}$ in $1.2 \mathrm{M} \mathrm{HCl}$ were added. The absorbance of the resulting solution at $670 \mathrm{~nm}$ was measured 20 min later with a Multiskan spectrum microplate spectrophotometer.

\section{Cell viability and proliferation assay}

Vascular smooth muscle cells of rat thoracic aorta (A7r5) were cultured in 96-well tissue culture plates $\left(1 \times 10^{4}\right.$ cells/well) with $10 \%$ FBS for $24 \mathrm{~h}$. Then the serum-free medium was used and cells were exposed to different reagents for another $24 \mathrm{~h}$. Cell viability and proliferation were measured respectively by the 3-(4,5-dimethylthiazol-2-yl)-2,5-diphenyltetrazolium bromide (MTT) [23] and 5-bromo-2'-deoxyuridine (BrdU) [10] incorporation assays.

\section{Immunofluorescence study}

The VSMCs were placed onto coverslips, which were covered in 24-well culture plates with polylysine. After cultured for $72 \mathrm{~h}$ at $37^{\circ} \mathrm{C}$, the VSMCs were washed with PBS, fixed with $4 \%$ formaldehyde in PBS for $10 \mathrm{~min}$, blocked in 1\% BSA for $30 \mathrm{~min}$. The cells were incubated with antibody against PCNA (1:100) or the P21 (Santa Cruz, CA) overnight at $4^{\circ} \mathrm{C}$. Then, the cells were incubated with secondary IgG (Santa Cruz, CA) (1:1000) conjugated with fluorescein isothiocyanate (FITC), for $1 \mathrm{~h}$ at $37^{\circ} \mathrm{C}$ and washed in PBS and $0.1 \%$ Tween 20. Fluorescence images were collected with a fluorescence microscope (Leica, Germany).

Total protein extraction from rat mesenteric secondary arteries and cultured vascular smooth muscle cells of rat thoracic aorta (A7r5) and protein analyzed by western blotting

Rat mesenteric secondary arteries and VSMCs were homogenized in $0.5 \mathrm{~mL}$ of RIPA buffer prior to being transferred into small tubes and rotated $1 \mathrm{~h}$ at $4{ }^{\circ} \mathrm{C}$. Solubilized proteins were collected after centrifugation at 3,000 $\times \mathrm{g}$ for $30 \mathrm{~min}$. The supernatant was collected and stored at $-80{ }^{\circ} \mathrm{C}$. The protein concentration of 


\section{Cellular Physiology Cell Physiol Biochem 2015;35:1582-1598 \begin{tabular}{l|l}
\hline and and 10.1159/000373973 & $\begin{array}{l}\text { C) } 2015 \text { S. Karger AG, Basel } \\
\text { www.karger.com/cpb }\end{array}$ \\
\hline
\end{tabular} \\ Zhong et al.: CaSR Regulating VSMCs Proliferation}

Table 1. General characteristic in control and diabetic rats (Dia: diabetes. ${ }^{*} p<0.05$ vs control, $\mathrm{n}=10$ )

\begin{tabular}{llll}
\hline & Food intake(g/day) & Water intake(ml/day) & Glucose $(\mathrm{mM})$ \\
\hline Control & $13.2 \pm 1.5$ & $27 \pm 3.1$ & $5.2 \pm 0.5$ \\
Dia 4w & $39.4 \pm 2.3^{*}$ & $183 \pm 4.9^{*}$ & $29.5 \pm 5.4^{*}$ \\
Dia 8w & $46.8 \pm 2.5^{*}$ & $228 \pm 5.6^{*}$ & $25.6 \pm 4.2^{*}$ \\
Dia 12w & $48.6 \pm 4.6^{*}$ & $231 \pm 4.2^{*}$ & $24.3 \pm 4.5^{*}$ \\
\hline
\end{tabular}

each sample was quantified using the enhanced BCA Protein Assay kit. To detect protein levels, protein lysates from each group of cells and tissues were separated by SDS-PAGE and electrotransferred onto a PVDF membrane (Millipore). Polyacrylamide gels (10 \%) were used for CSE (42 kDa), CaSR (90-150 kDa), Cyclin D1 (36 kDa), $\alpha$-smooth muscle actin (42 kDa), calponin (34 kDa), MMP9 (67-92 kDa) and p-CaMK II (54 $\mathrm{kDa}$ ) protein testing. The nonspecific proteins on membranes were blocked with $5 \%$ nonfat dried skimmed milk powder prepared in TBS $+0.2 \%$ Tween 20 for $2 \mathrm{~h}$ at room temperature. Immunoblotting was then performed using $2 \mu \mathrm{g} / \mathrm{mL}$ rabbit anti-rat CSE, calponin, MMP9, p-CaMK II and CaSR antibodies, rabbit antihuman Cyclin D1 and $\alpha$-smooth muscle actinpolyclonal antibody, respectively. Membrane blots were washed and incubated with anti-rabbit or mouse IgG antibodies at a 1:1,000 dilution. Immunoreactive proteins were then visualized using AP colorimetric analysis. The volume of the protein bands was quantified using a Bio-Rad Chemi EQ densitometer and Bio-Rad Quantity One software (Bio-Rad laboratories, Hercules, USA).

\section{Statistical analysis}

Data are expressed as mean \pm SEM. All data involving multiple groups were analyzed by one-way ANOVA. Differences between individual groups were analyzed using the Student's $t$ test. A difference with $\mathrm{P}<0.05$ was considered statistically significant.

\section{Results}

General characteristics and blood glucose in diabetic rats

To investigate the in vivo effect of $\mathrm{H}_{2} \mathrm{~S}$ on diabetic vessels, we first established a diabetic rat model by injecting rats with STZ. Compared with the control group, food and water intake and the concentration of blood glucose were significantly increased in the 4, 8 and 12 week diabetic groups. These results demonstrated that our rat diabetic model was established successfully (Table 1 ).

Exogenous $\mathrm{H}_{2} \mathrm{~S}$ decreased the thickness of smooth muscle in the mesenteric secondary arteries of diabetic rats

To explore the in vivo effect of $\mathrm{H}_{2} \mathrm{~S}$ on the proliferation of smooth muscle in the mesenteric secondary arteries of diabetic rats, the thickness of the mesenteric artery was evaluated by TEM. Compared with the control group, the thickness of the smooth muscle significantly increased and the $\mathrm{H}_{2} \mathrm{~S}$ concentration decreased in the mesenteric arteries of the 4, 8 and 12 week diabetic groups. The thickness of the smooth muscle and the $\mathrm{H}_{2} \mathrm{~S}$ concentration in the groups treated with NaHS obviously improved compared with the diabetic groups (Fig. 1).

\section{Protein expression in the mesenteric arteries of diabetic rats}

Our results showed that compared with the control group, the expression of CaSR and CSE decreased while Cyclin D1 expression increased in the 4, 8 and 12 week diabetic groups, while the expression of these proteins reversed in the NaHS treatment groups (Fig. 2).

CaSR or H2S increased the relaxation rate of the mesenteric artery rings of diabetic rats

Functional changes in vessels are critical indicators of vascular injury. To investigate the effects of CaSR and $\mathrm{H}_{2} \mathrm{~S}$ on the functional changes of mesenteric artery rings, we 


\section{Cellular Physiology Cell Physiol Biochem 2015;35:1582-1598 \begin{tabular}{c|c|c|c|}
\hline DOI: 10.1159/000373973 & ( ) 2015 S. Karger AG, Bas
\end{tabular} \\ Zhong et al.: CaSR Regulating VSMCs Proliferation}

Fig. 1. Ultrastructural alterations and the $\mathrm{H}_{2} \mathrm{~S}$ concentration of rat mesenteric arteries (A: A1-A3, Diabetes 4-12w; B1-B3, Diabetes + NaHS 4-12w; Diabetes 4-12w vs. control, ${ }^{*} p<0.05$; Diabetes + NaHS $4-12 \mathrm{w}$ vs Diabetes $4-12 \mathrm{w},{ }^{*} p<0.05$; as detected by EM $(3000 \times)$; B Thickness of smooth muscle in Rat mesenteric arteries $(\mu \mathrm{m})$ and $\mathrm{C}_{2} \mathrm{~S}$ concentration $(\mu \mathrm{M})$ of Rat mesenteric arteries: Diabetes 4-12w vs. control and Diabetes + NaHS $4-12 w$ vs. Diabetes $4-12 w$, respectively, ${ }^{*} p<0.05 . \mathrm{n}=6-8$ )

examined the relaxation of mesenteric artery rings subjected to CaSR or NaHS treatment. Compared with the control group, the relaxation rates of the mesenteric artery rings of the 4,8 and 12 week diabetic groups decreased dramatically. In contrast, the relaxation rates significantly increased after treatment with NaHS compared with the diabetic groups after treatment with Calindol $(5 \mu \mathrm{M}$, a CaSR specific agonist) or NaHS (60 $\mu \mathrm{M}, \mathrm{H}_{2} \mathrm{~S}$ donor) (Fig. 3).

CaSR activation induced an increase in $\left[\mathrm{Ca}^{2+}\right]_{i}$ in VSMCs via the PLC-IP3 signal transduction pathway and modulated the expression of CSE via $p$-CaMKII

To investigate the relationship between CSE and CaSR activation, we examined the signal transduction pathways among $\mathrm{CaSR},\left[\mathrm{Ca}^{2+}\right]_{i}$ and CSE. We found that the FI of $\left[\mathrm{Ca}^{2+}\right]_{i}$ was significantly increased in the CaSR agonist $\left(\mathrm{CaCl}_{2}\right.$ and Calindol) group compared with the control group. The FI of $\left[\mathrm{Ca}^{2+}\right]_{\mathrm{i}}$ was decreased in the Calindol (Calhex231/2-APB/U73122/ TG pretreated) and $\mathrm{CaCl}_{2}\left(\mathrm{NiCl}_{2}+\right.$ $\mathrm{CdCl}_{2}+$ Calhex231/2-APB/U73122/ TG pretreated) experimental groups compared with the CaSR agonist group. Furthermore, as a negative control, BAPTA had an obvious effect on the FI of $\left[\mathrm{Ca}^{2+}\right]_{\mathrm{i}}$. Western blot analysis showed that, compared with the control group, the expression of p-CaMK II and CSE increased in the CaSR agonist group; in contrast, the expression of CSE decreased in the KN93-pretreated $(10 \mu \mathrm{M}$, calmodulin antagonist) group compared with the CaSR agonist group (Fig. 5).

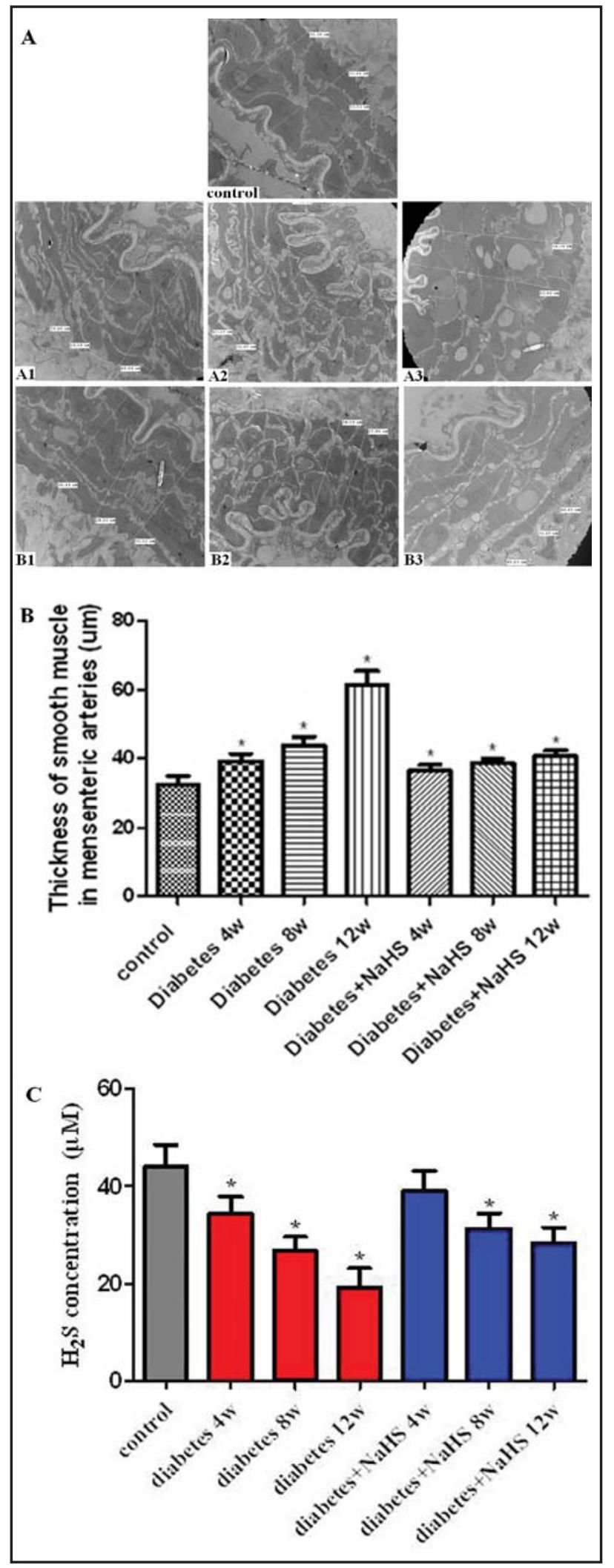




\section{Cellular Physiology Cell Physiol Biochem 2015;35:1582-1598 \begin{tabular}{c|c|c|}
\hline DOI: 10.1159/000373973 & O 2015 S. Karger AG, Bas
\end{tabular} \\ Zhong et al.: CaSR Regulating VSMCs Proliferation}

Fig. 2. Protein expression at $4-12 \mathrm{w}$ in diabetic rat mesenteric arteries determined by Western blot (A: 4 weeks, CSE expression was decreased while Cyclin D1 expression increased in diabetes group and diabetes + NaHS vs. diabetes, ${ }^{*} p<0.05$; B: 8 weeks, the expression of CaSR and CSE was decreased while the expression of Cyclin D1 increased in diabetes group and diabetes + NaHS vs diabetes, CaSR: ${ }^{*} p<0.01$ and $\# p<0.05$; Cyclin D1: ${ }^{*} p<0.01$ and $\# p<0.01$; CSE: ${ }^{*} p<0.05$; C: 12 weeks, CaSR, CSE expression were decreased while Cyclin D1 increased in diabetes group and diabetes + NaHS vs. diabetes, CaSR: ${ }^{*} p<0.05$; Cyclin D1: ${ }^{*} p<0.01$ and $\# p<0.05$; CSE: ${ }^{*} p<0.01$ and $\# p<0.05$. $\mathrm{n}=4$ ).

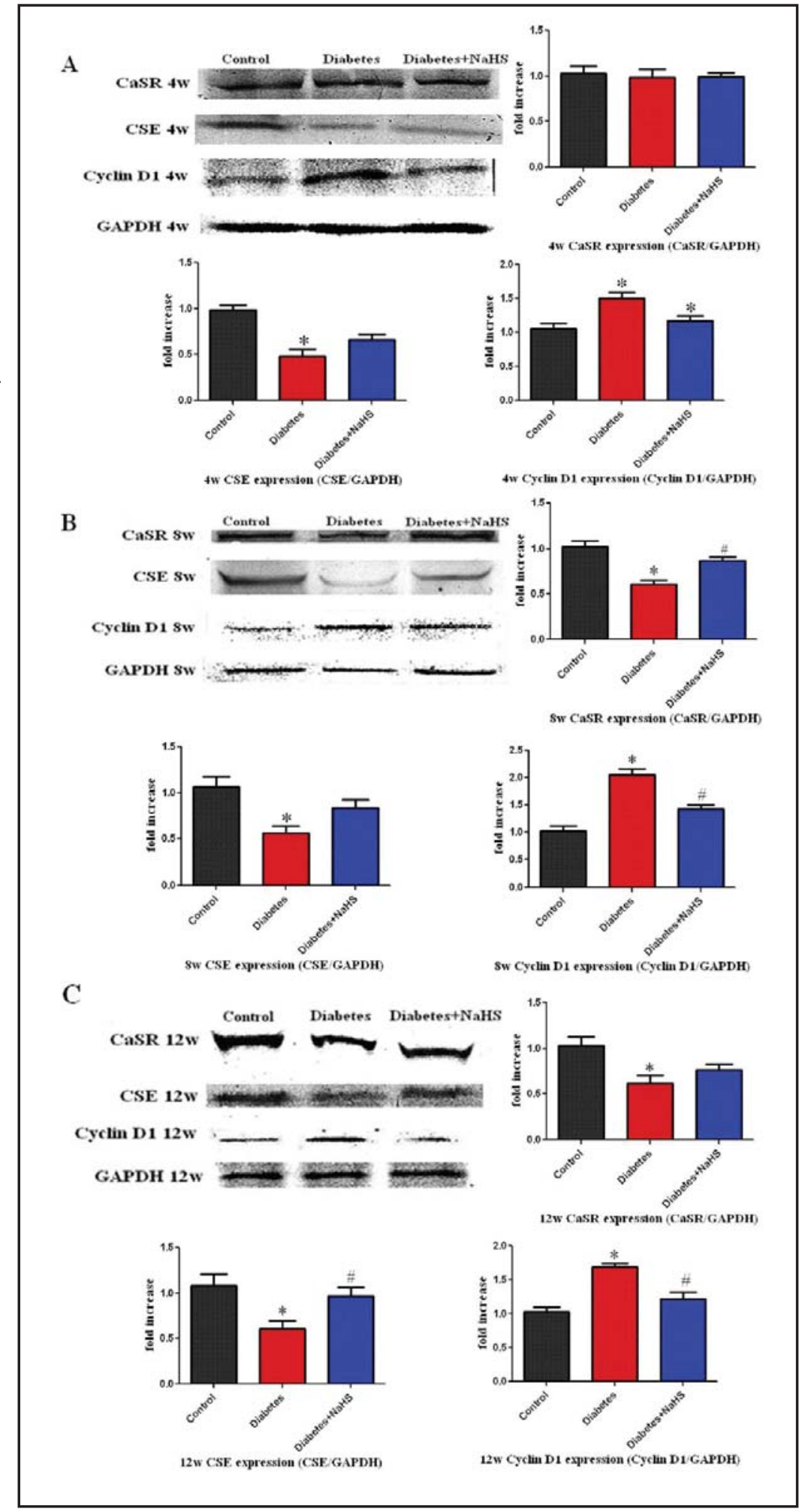

CaSR activation mediated the CSE $/ \mathrm{H}_{2}$ S pathway in VSMCS

To further explore the modulation of $\mathrm{CSE} / \mathrm{H}_{2} \mathrm{~S}$ by CaSR activation, we also examined the effect of CaSR agonists that mediate the $\mathrm{CSE} / \mathrm{H}_{2} \mathrm{~S}$ pathway of VSMCs both in low and high glucose. CaSR agonists $\left(\mathrm{CaCl}_{2}\right.$ or Calindol) increased the expression of CaSR compared with the control (5.56 mM glucose, LG) group of VSMCs from the rat thoracic aorta. $\mathrm{CaCl}_{2}$ 


\section{Cellular Physiology Cell Physiol Biochem 2015;35:1582-1598 \begin{tabular}{l|l|l} 
DOI: 10.1159/000373973 & O 2015 S. Karger AG, Basel
\end{tabular} and Biochemistry Published online: March 18, 2015 www.karger.com/cpb

Fig. 3. The changes of relaxation rate in mesenteric artery rings after the treatment with Calindol or NaHS (A: The changes of relaxation rate of $4-12 w$ Dia were decreased while 4-12w Dia + NaHS were increased after treated with Calindol. 4-12w Dia vs. Control, $\# p<0.01$; $8 \mathrm{w}$ and $12 \mathrm{w}$ Dia vs. $4 \mathrm{w}$ Dia, $\# p<0.01$; $4 \mathrm{w}$ Dia + NaHS vs. $4 \mathrm{w}$ Dia, ${ }^{*} p<0.05 ; 8 \mathrm{w}$ and $12 \mathrm{w}$ Dia + NaHS vs. $8 \mathrm{w}$ and $12 \mathrm{w}$ Dia, $\# p<0.01$. B: The changes of relaxation rate of $4-12 w$ Dia were decreased while that of 4-12w Dia + NaHS were increased after treated with NaHS. 4-12w Dia vs. Control, $\# p<0.01 ; 12 \mathrm{w}$ Dia vs. $4 \mathrm{w}$ and $8 \mathrm{w}$ Dia, ${ }^{*} p<0.05$; $4 \mathrm{w}$ and $8 \mathrm{w}$ Dia + NaHS vs. $4 \mathrm{w}$ and $8 \mathrm{w}$ Dia, ${ }^{*} p<0.05$; $12 \mathrm{w}$ Dia + NaHS vs. 12w Dia, $\# p<0.01$. C: $4-12$ w Diabetes vs. Control, $\# p<0.01$; Diabetes + NaHS vs. Diabetes, ${ }^{*} p<0.05, \# p<0.01$; and $12 \mathrm{w}$ Diabetes vs. $4 \mathrm{w}$ and $8 \mathrm{w}$ Diabetes, ${ }^{*} \# p<0.05$. $\mathrm{n}=4-6$. Dia means Diabetes). The curves ( $A$ and $B$ ) show the changes of the relaxation rate at different time, and the bar graph (C) shows the relaxation rate at the $5 \mathrm{~min}$ point.
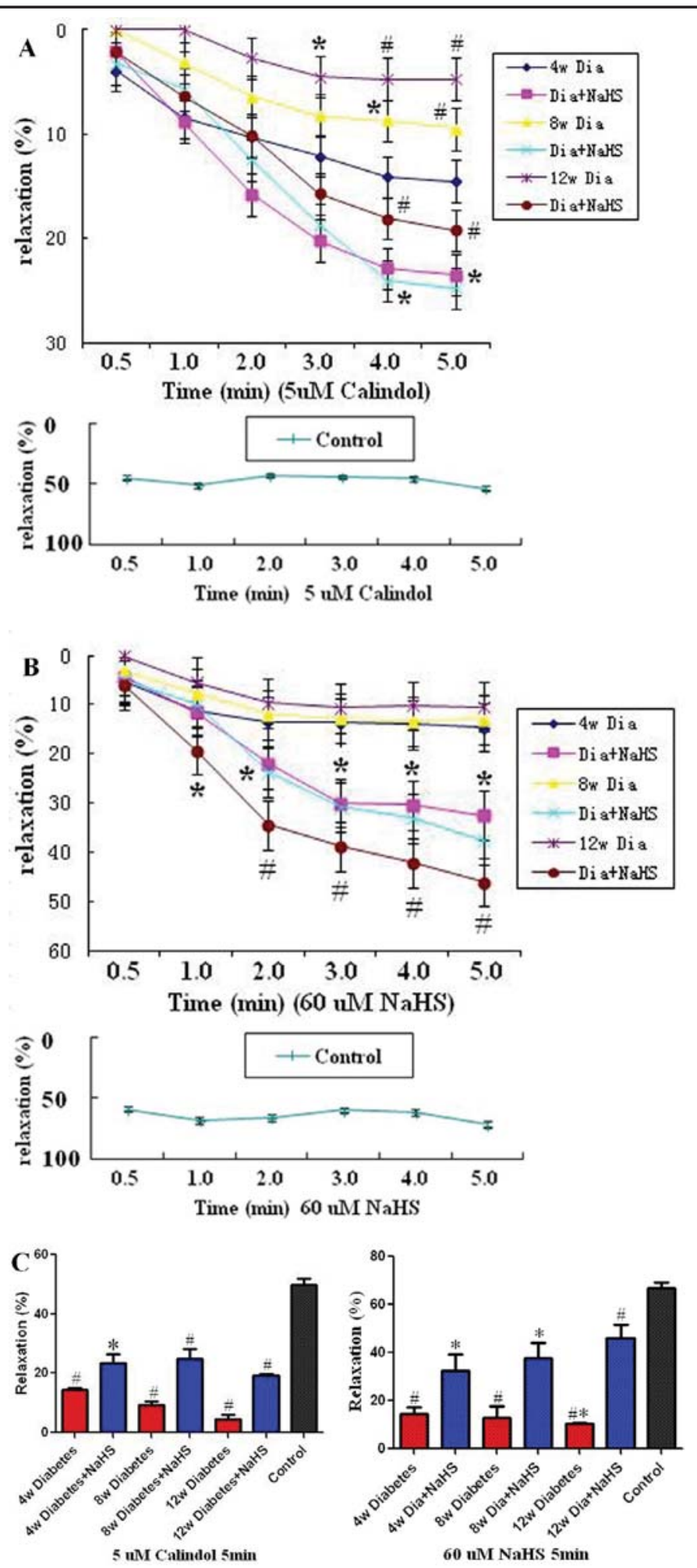

also increased the expression of CSE compared with the control group. In contrast, the expression of CSE was decreased in the pretreated BAPTA groups compared with the $\mathrm{CaCl}_{2}$ group. Both $\mathrm{CaCl}_{2}$ and Calindol increased $\mathrm{H}_{2} \mathrm{~S}$ production in the VSMCs compared with the control group, while $\mathrm{H}_{2} \mathrm{~S}$ production was decreased in the EGTA (calcium chelator), BAPTA and 2-APB groups compared with the CaSR agonist group (Fig. 4). 


\section{Cellular Physiology Cell Physiol Biochem 2015;35:1582-1598 \begin{tabular}{|l|l|l}
\hline DOI: 10.1159/000373973 & O 2015 S. Karger AG, Basel
\end{tabular} and Biochemistry Published online: March 18, $2015 \quad$ www.karger.com/cpb

A CaSR LG $\quad \mathrm{LG}+\mathrm{CaCl}_{2} \quad \mathrm{LG}+\mathrm{C}$ alindol $\quad \mathrm{LG}+\mathrm{C}$ allhex231
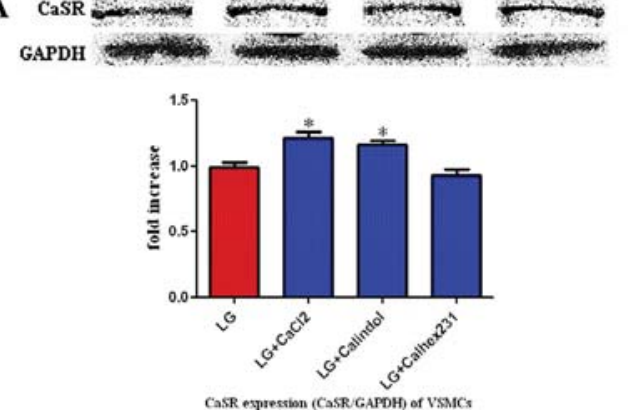

C

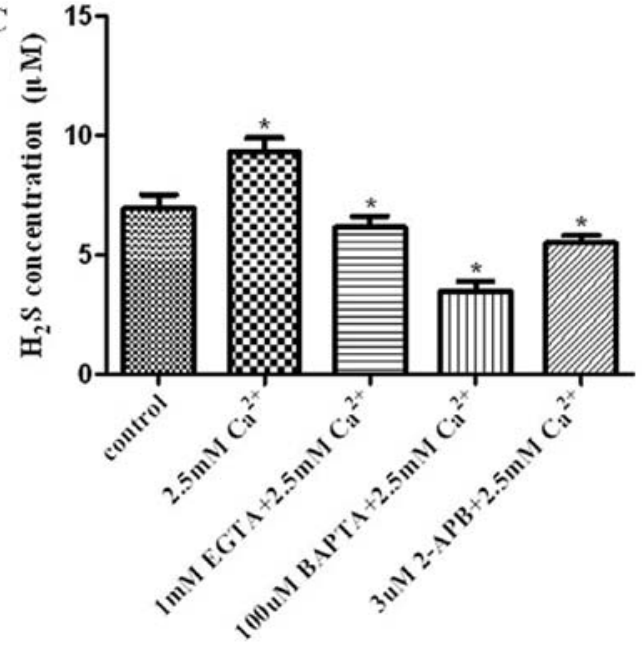

\section{B}
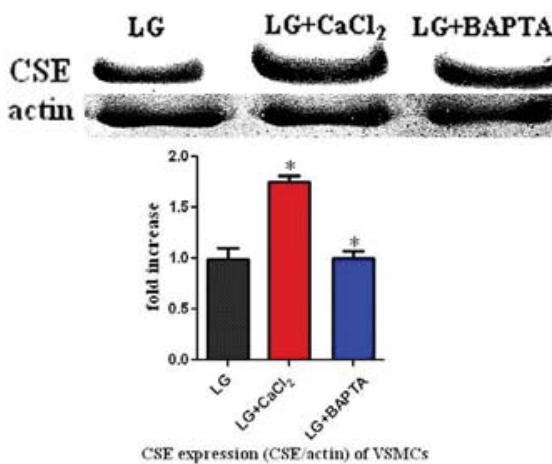

D

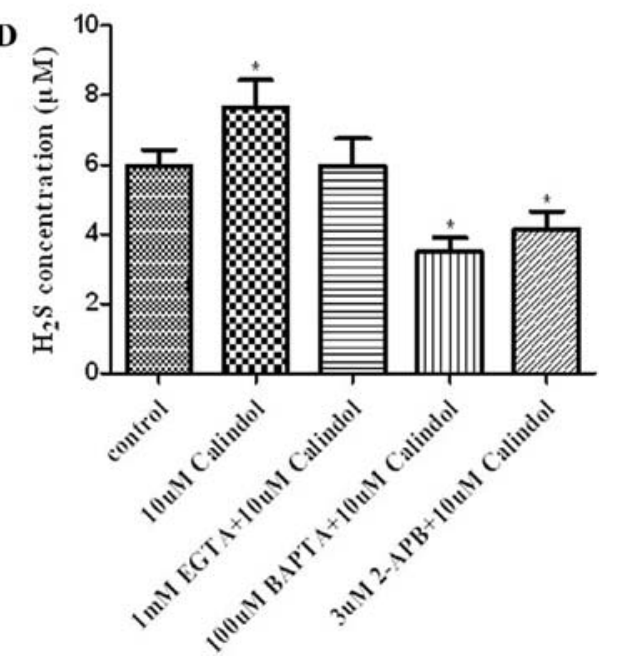

Fig. 4. CaSR activation mediated the $\mathrm{CSE} / \mathrm{H}_{2} \mathrm{~S}$ pathway of VSMCs cultured in low glucose DMEM (control or LG, $5.56 \mathrm{mM}$ glucose. A CaSR expression was increased by the Calindol and $\mathrm{CaCl}_{2}: \mathrm{LG}+\mathrm{CaCl}_{2} / \mathrm{Calindol}_{\mathrm{vs}} \mathrm{LG}$, ${ }^{*} P<0.05$; B CSE expression was increased by $\mathrm{CaCl}_{2}: \mathrm{LG}+\mathrm{CaCl}_{2}$ vs. LG, LG + BAPTA vs. LG $+\mathrm{CaCl}_{2},{ }^{*} p<0.05 ; \mathrm{C}$ $\mathrm{H}_{2} \mathrm{~S}$ concentration $(\mu \mathrm{M})$ of VSMCs: $\mathrm{Ca}^{2+}$ vs. control, $\mathrm{EGTA}+\mathrm{Ca}^{2+} \mathrm{vs}^{2} \mathrm{Ca}^{2+}, \mathrm{BAPTA}+\mathrm{Ca}^{2+}$ vs. $\mathrm{Ca}^{2+}, 2-\mathrm{APB}+\mathrm{Ca}^{2+}$ vs. $\mathrm{Ca}^{2+},{ }^{*} p<0.05$; and D: Calindol vs. control, BAPTA + Calindol vs. Calindol, $2-\mathrm{APB}+$ Calindol vs. Calindol, $* p<0.05 . \mathrm{n}=4-5)$.

In the high glucose (HG, $25 \mathrm{mM}$ glucose) group of VSMCs from the rat thoracic aorta, the expression levels of CaSR and CSE and CSE activity significantly decreased compared with the control group. These changes obviously increased in the Calindol, $\mathrm{CaCl}_{2}, \mathrm{NaHS}$ and A23187 $\left(\mathrm{Ca}^{2+}\right.$ transporter) groups compared with the $\mathrm{HG}$ group. We also measured $\mathrm{H}_{2} \mathrm{~S}$ production in the different groups; $\mathrm{H}_{2} \mathrm{~S}$ concentration was decreased in the HG group compared with the control group, whereas the CaSR agonist increased the $\mathrm{H}_{2} \mathrm{~S}$ level compared with the HG group (Fig. 6).

$\mathrm{H}_{2} \mathrm{~S}$ inhibited the alteration of the VSMC phenotype, as observed with Masson's trichrome staining and western blot analysis

A previous study showed that VSMCs proliferate after the phenotypic modulation from a contractile state to a proliferative state [24]. To test the inhibition of $\mathrm{H}_{2} \mathrm{~S}$ on the proliferation of VSMCs in diabetic rats, we examined the interstitial fibrotic areas of the mesenteric arteries and the expression of related proteins in VSMCs. The results of Masson's trichrome staining showed that, compared with the control group, the interstitial fibrotic areas of the smooth muscle layer in the diabetic group were significantly increased, while the interstitial fibrotic areas reduced in the diabetes + NaHS group. Western blot analysis showed that the expression of $\alpha$-smooth muscle actin and calponin decreased while MMP-9 increased in the 


\section{Cellular Physiology Cell Physiol Biochem 2015;35:1582-1598 \begin{tabular}{|l|l|}
\hline DOI: 10.1159/000373973 & 2015 S. Karger AG, Basel
\end{tabular} \begin{tabular}{l|l} 
and Biochemistry Published online: March 18, 2015 & www.karger.com/cpb \\
\hline
\end{tabular}

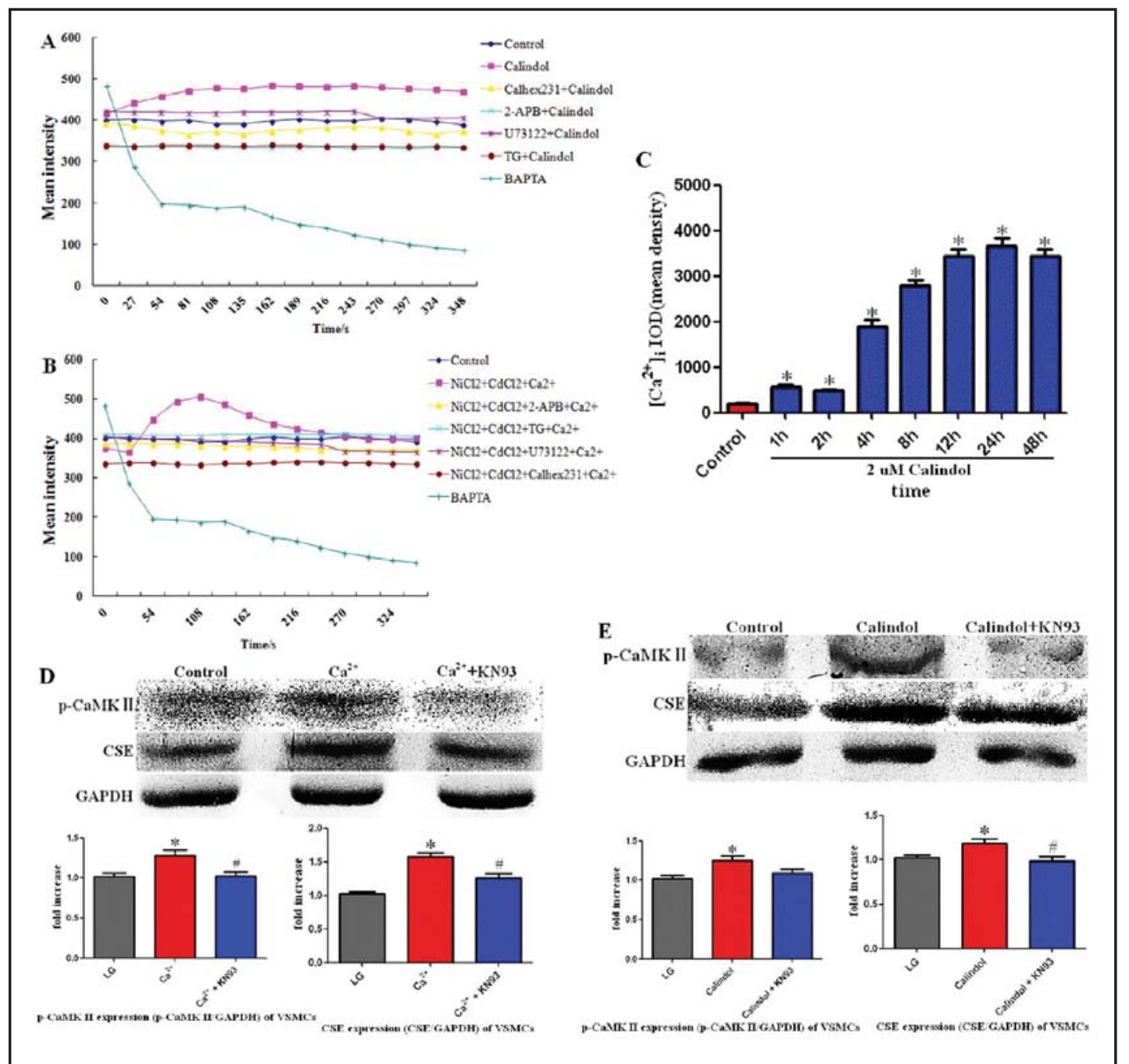

Fig. 5. The effect of a CaSR agonist on the $\left[\mathrm{Ca}^{2+}\right]_{\mathrm{i}}$ and p-CaMK II in A7r5 cells (A and B: $2 \mu \mathrm{M}$ Calindol or 2.5 $\mathrm{mM} \mathrm{CaCl}_{2}$ caused an increased FI of $\left[\mathrm{Ca}^{2+}\right]_{\mathrm{i}^{\prime}} p<0.05 \mathrm{vs}$. control, and pretreatment with $3 \mu \mathrm{M}$ calhex $231,10 \mu \mathrm{M}$ U73122, $75 \mu \mathrm{M}$ 2-APB and $10 \mu \mathrm{M}$ TG decreased or abolished the increased FI of $\left[\mathrm{Ca}^{2+}\right]_{\mathrm{i}}$ induced by Calindol or $\mathrm{CaCl}_{2}$. BAPTA obviously decreased the FI of $\left[\mathrm{Ca}^{2+}\right]_{\mathrm{i}}$ compared with the control, $p<0.01$; C: $2 \mu \mathrm{M}$ Calindol increased the integrated optical density of $\left[\mathrm{Ca}^{2+}\right]_{\mathrm{i}}{ }^{*} p<0.01$ vs. control; D and E: $\mathrm{p}$-CaMK II and CSE expression after treated with Calindol or $\mathrm{Ca}^{2+}$ determined by Western blot. Calindol or $\mathrm{Ca}^{2+}$ vs. $\mathrm{LG},{ }^{*} p<0.05$; Calindol + KN93 or $\mathrm{Ca}^{2+}+\mathrm{KN} 93$ vs. Calindol or $\mathrm{Ca}^{2+}$, respectively, \#p<0.05; $\mathrm{n}=4-5$ ).

HG group compared with the control group. The expression levels of these proteins reversed after treatment with NaHS compared with the HG group (Fig. 7).

CaSR activation mediated the CSE $/ \mathrm{H}_{2} S$ pathway, which inhibited VSMC proliferation

Treatment with $25 \mathrm{mM}$ HG significantly increased cell viability and proliferation of A7r5 compared with the control group. However, cell viability and proliferation decreased in the Calindol, $\mathrm{CaCl}_{2}, \mathrm{NaHS}$ and $\mathrm{A} 23187$ groups compared with the HG group based on the cell viability data (MTT) and cell proliferation analysis (BrdU). Immunofluorescence staining showed that the expression of proliferating cell nuclear antigen (PCNA) increased while P21 decreased in HG group compared with the control group. In contrast, the expression of PCNA and P21 reversed in the Calindol, NaHS and A23187 groups compared with the HG group (Fig. 8). 


\section{Cellular Physiology Cell Physiol Biochem 2015;35:1582-1598 \begin{tabular}{|l|l|}
\hline DOI: 10.1159/000373973 & (C) 2015 S. Karger AG, Basel
\end{tabular} and Biochemistry Published online: March 18, $2015 \quad$ www.karger.com/cpb

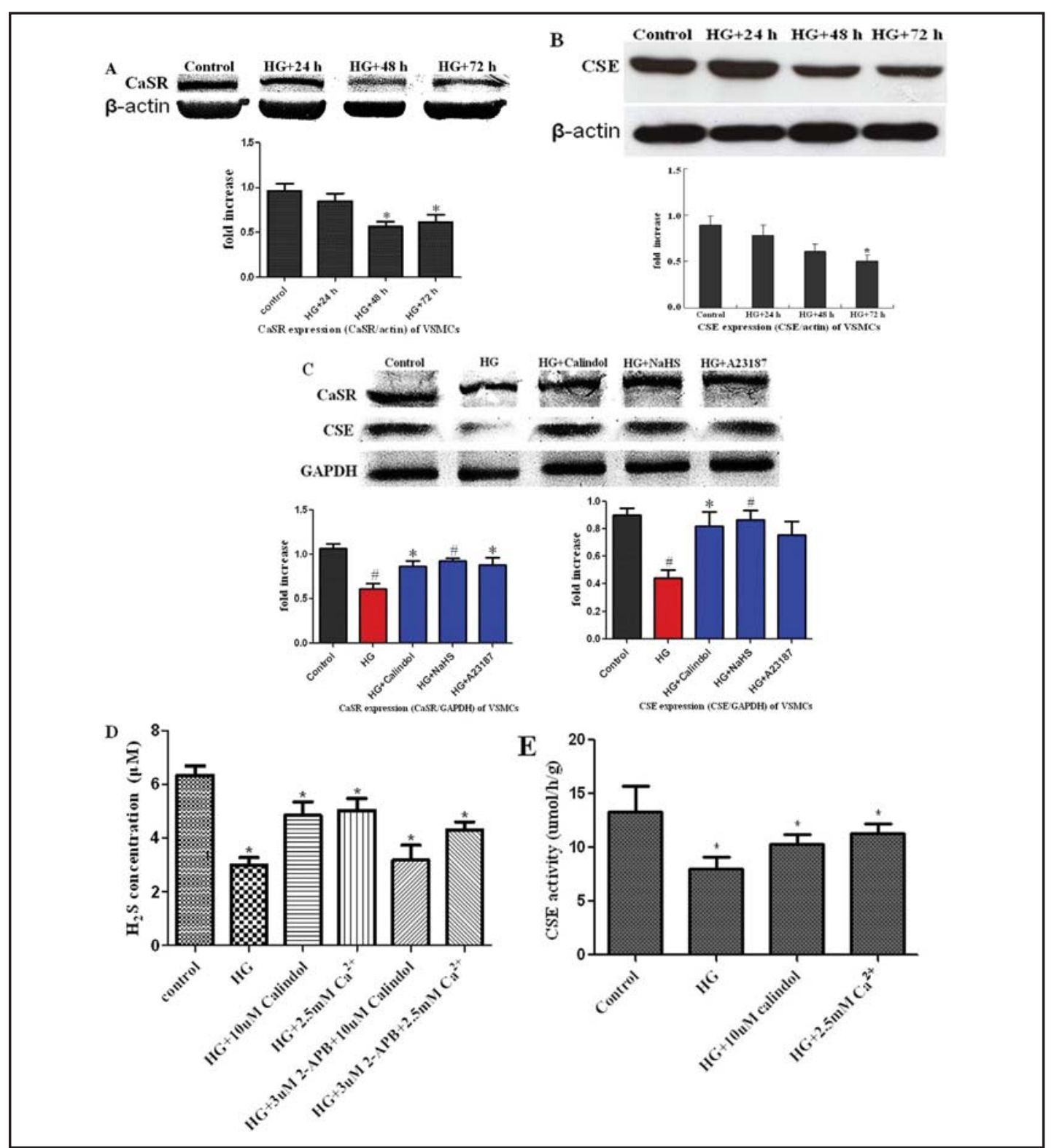

Fig. 6. CaSR activation mediated the CSE/ $\mathrm{H}_{2} \mathrm{~S}$ pathway in VSMCs (control, $5.56 \mathrm{mM}$ glucose; $\mathrm{HG}, 25 \mathrm{mM}$ glucose. A: $\mathrm{HG}+48 \mathrm{~h}$ and $\mathrm{HG}+72 \mathrm{~h}$ vs. Control, ${ }^{*} p<0.05$; $\mathrm{B}$ : $\mathrm{HG}+72 \mathrm{~h}$ vs. Control, ${ }^{*} p<0.05$; C: The expression of CaSR and CSE was decreased in HG. CaSR: HG vs. Control, $\# p<0.01 ; \mathrm{HG}+$ Calindol vs. HG: * $p<0.05 ; \mathrm{HG}+$ NaHS vs. HG: $\# p<0.01 ; H G+A 23187$ vs. HG: ${ }^{*} p<0.05$; and CSE: HG vs. Control, \#p<0.01; HG + Calindol vs. HG, ${ }^{*} p<0.05 ; \mathrm{HG}+\mathrm{NaHS}$ vs HG, \#p<0.01; $\mathrm{D} \mathrm{H}_{2} \mathrm{~S}$ concentration $(\mu \mathrm{M})$ of VSMCs: HG vs. control, $\mathrm{HG}+\mathrm{Ca}^{2+} /$ Calindol vs. HG, HG $+2-\mathrm{APB}+\mathrm{Ca}^{2+} /$ Calindol vs. $\mathrm{HG}+\mathrm{Ca}^{2+} /$ Calindol, ${ }^{*} p<0.05$; and $\mathrm{E}$ CSE activity $(\mu \mathrm{mol} / \mathrm{h} / \mathrm{g}): \mathrm{HG}$ vs. control, $\mathrm{HG}+\mathrm{Ca}^{2+} /$ Calindol vs. $\left.\mathrm{HG},{ }^{*} p<0.05 . \mathrm{n}=4-5\right)$.

\section{Discussion}

The proliferation of VSMCs plays a key role in the maintenance of vascular structure and functions. However, its phenotypic alteration leads to vascular remodeling and various proliferative vascular diseases [25]. High glucose induces VSMC proliferation in vitro, mimicking a key process involved in subendothelial arterial wall thickening and subsequent progression to atherosclerosis in diabetic patients [26]. Recently, some studies suggested that vasodilators such as nitric oxide (NO), play a major role in modulating the alteration 


\section{Cellular Physiology Cell Physiol Biochem 2015;35:1582-1598 \begin{tabular}{|l|l|}
\hline DOI: 10.1159/000373973 & (c) 2015 S. Karger AG, Basel
\end{tabular} \begin{tabular}{l|l} 
and Biochemistry Published online: March 18, 2015 & www.karger.com/cpb \\
\hline
\end{tabular}

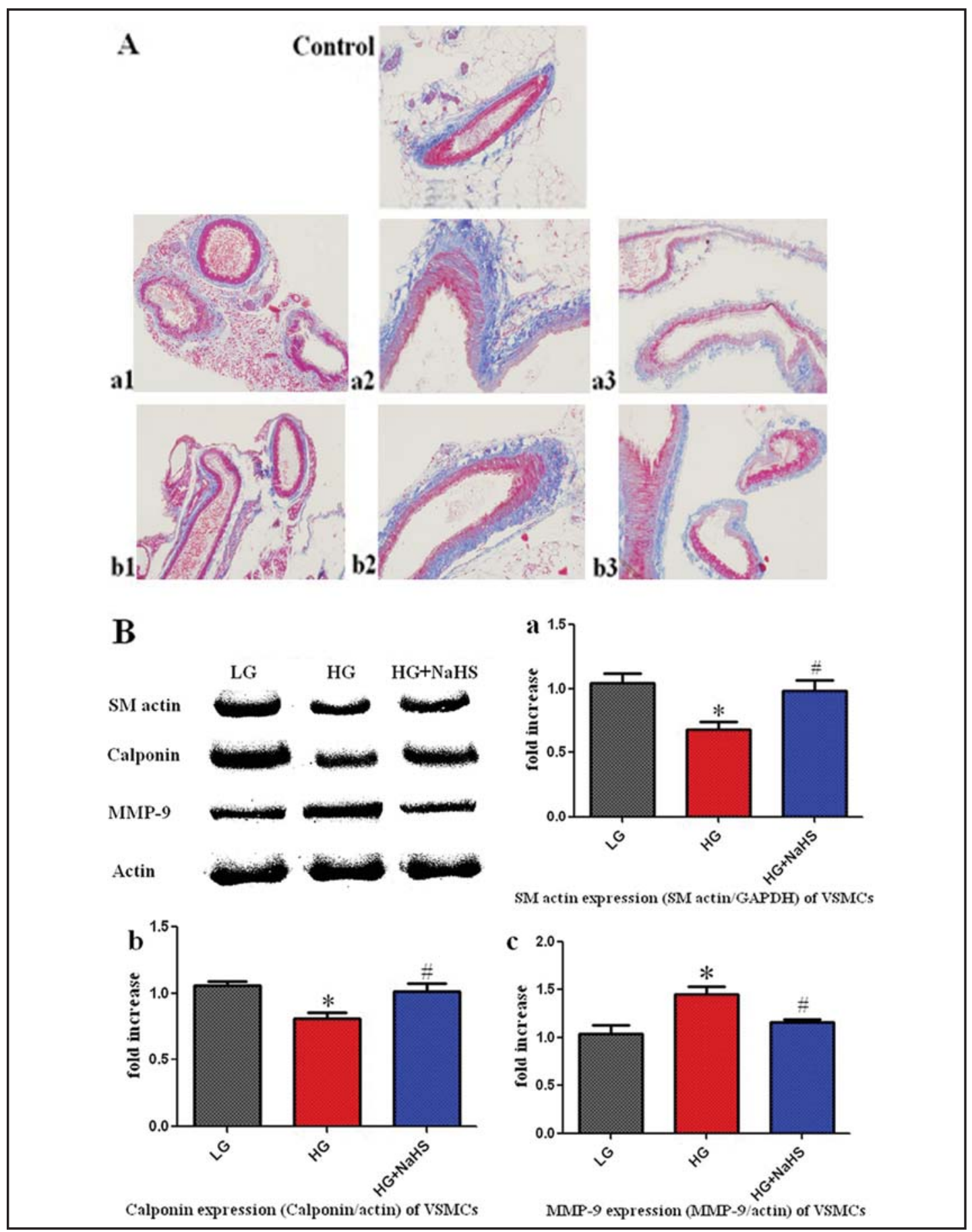

Fig. 7. Masson's trichrome staining of rat mesenteric arteries and protein expression levels in VSMCs (A: the interstitial fibrotic areas of the smooth muscle layer in the diabetic group were increased while those reduced in the diabetes + NaHS group. a1-a3, 4w-12w Diabetes; b1-b3, 4w-12w Diabetes + NaHS, $(40 \times)$. B: The $\alpha$-smooth muscle actin (a), Calponin (b) and MMP-9 (c) expression determined by Western blot. HG vs. LG, ${ }^{*} p<0.05$ and $H G+$ NaHS vs. HG, $\left.\# p<0.05 . \mathrm{n}=4-6\right)$.

of phenotype and proliferation of VSMCs in diabetic models [5]. Similar to $\mathrm{NO}, \mathrm{H}_{2} \mathrm{~S}$ has also been suggested to regulate VSMCs proliferation [27]. Growing evidence supports $\mathrm{H}_{2} \mathrm{~S}$ as an important endogenous modulator of cell proliferation and apoptosis. Overexpression of CSE in human aortic SMCs inhibited cell growth and induced cell apoptosis [28]. The absence of 


\section{Cellular Physiology Cell Physiol Biochem 2015;35:1582-1598 \begin{tabular}{l|l|l} 
DOI: 10.1159/000373973 & O 2015 S. Karger AG, Basel
\end{tabular} and Biochemistry Published online: March 18, 2015 www.karger.com/cpb

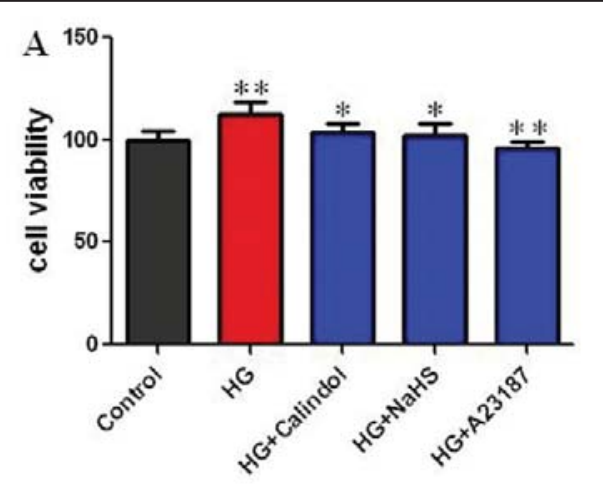

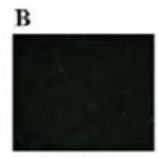

Control

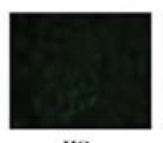

HG

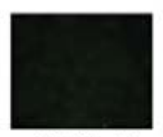

HG+Catindol

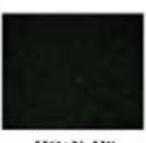

HG+NaHS

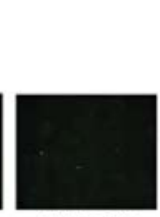

HG+A231s7
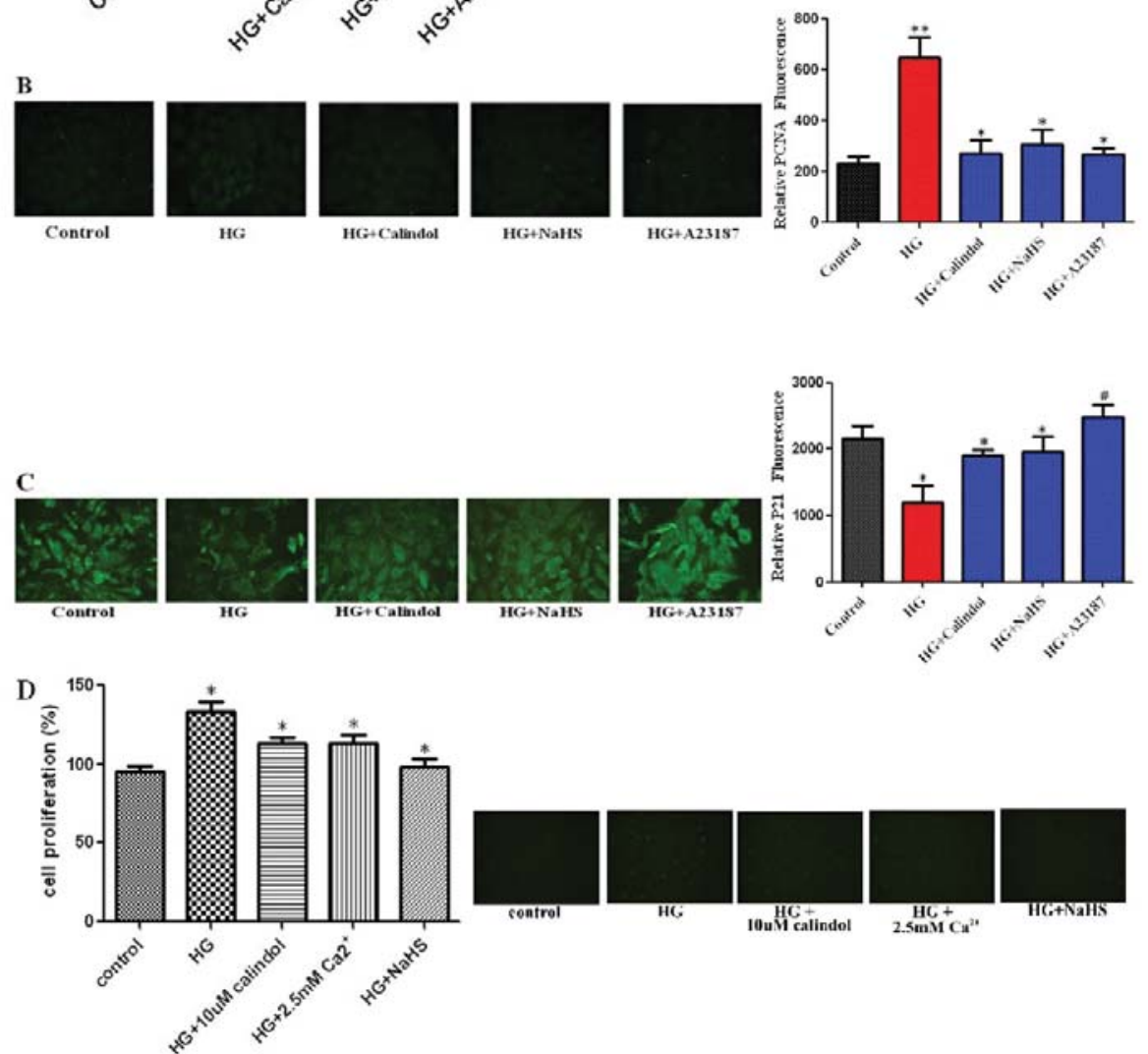

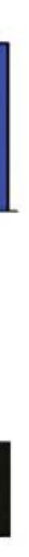

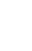




\section{Cellular Physiology Cell Physiol Biochem 2015;35:1582-1598 \\ \begin{tabular}{l|l} 
and Biochemistry $\begin{array}{l}\text { DOI 10.1159/000373973 } \\
\text { Published online: March 18, } 2015\end{array}$ & $\begin{array}{l}\text { (c) 2015 S. Karger AG, Basel } \\
\text { www.karger.com/cpb }\end{array}$ \\
\hline Znong
\end{tabular}}

As a G-protein coupled receptor, CaSR initiates intracellular signals through the modulation of a series of intracellular signaling proteins, including G proteins and PLC, and promotes $\left[\mathrm{Ca}^{2+}\right]_{i}$ release from the endoplasmic/sarcoplasmic reticulum $[29,30]$. Our previous study proved that the activation of CaSR induced the release of $\mathrm{Ca}^{2+}$ from endoplasmic/ sarcoplasmic reticulum and increased the intracellular calcium concentration [30].

Previous studies suggested that endogenous $\mathrm{H}_{2} \mathrm{~S}$, which is a strong vasodilator, can be produced by cystathionine-gamma-lyase (CSE) or cystathionine-beta-synthase (CBS) [31]. In mammalian cardiovascular tissues, the biosynthesis of $\mathrm{H}_{2} \mathrm{~S}$ is mainly catalyzed by CSE [32]. A recent study found that the elevation of $\left[\mathrm{Ca}^{2+}\right]_{\mathrm{i}}$ increased CSE activity and the vasodilator production in smooth muscle cells $[8,19]$. However, whether CaSR plays a role in the modulation of $\mathrm{CSE} / \mathrm{H}_{2} \mathrm{~S}$ and, in turn, influences the vasorelaxation and proliferation of VSMCs has been poorly explored. Our data prove that, in response to low glucose, CaSR agonists increased the $\left[\mathrm{Ca}^{2+}\right]_{i}$ of VSMCs in a time-dependent manner. Further, pretreatment with the CaSR inhibitor calhex231, PLC-IP ${ }_{3}$ receptor pathway inhibitor (U73122 or 2-APB) or chelating the intracellular free calcium with BAPTA significantly inhibited the increase of $\left[\mathrm{Ca}^{2+}\right]_{\mathrm{i}}$ induced by Calindol (Fig. $5 \mathrm{~A}$ and $\mathrm{C}$ ) or $\mathrm{CaCl}_{2}$ (Fig 5B). The results are in accordance with previous study $[30,33]$ and suggest that CaSR is involved in the increase of $\left[\mathrm{Ca}^{2+}\right]_{\mathrm{i}}$ and that the activation of CaSR increased the $\left[\mathrm{Ca}^{2+}\right]_{\mathrm{i}}$ through the PLC-IP ${ }_{3}$ receptor pathway. Moreover, CaSR and CSE expression and the $\mathrm{H}_{2} \mathrm{~S}$ concentration in VSMCs were increased in response to treatment with CaSR agonists (Fig 4A, B). In contrast, chelating extracellular calcium with EGTA or intracellular free calcium with BAPTA inhibits the effect of CaSR activation on $\mathrm{H}_{2} \mathrm{~S}$ concentration (Fig 4C, D).

Some studies [8] have demonstrated that $\mathrm{H}_{2} \mathrm{~S}$ generation by CSE is physiologically regulated by calcium-calmodulin. In this study, CaSR activation increased the expression of p-CaMK II and CSE (Fig 5D, E), while the calmodulin antagonist KN93 inhibited the expression of CSE; these results indicate that CaSR modulates the expression of CSE through the calcium-calmodulin pathway of VSMCs. The above results also demonstrated that the rates of $\left[\mathrm{Ca}^{2+}\right]_{\mathrm{i}}$ increase induced by Calindol are much slower and the elevated $\left[\mathrm{Ca}^{2+}\right]_{\mathrm{i}}$ levels persisted longer. Thus, we reasoned that the CaSR-induced upregulation of CSE expression may be related to the kinetics and the sustained increase levels of $\left[\mathrm{Ca}^{2+}\right]_{i}$.

VSMCs proliferation is a critical factor and is characteristic of diabetes or hyperglycemia. In the present study, we generated the diabetic rat model (Table 1) and confirmed that the SMCs proliferated in the mesenteric arteries (Fig 1A-B). In addition, changes in the relaxation rate of the diabetic rats' mesenteric arteries were evaluated to assess the function of vessels. It has been demonstrated that the $\mathrm{H}_{2} \mathrm{~S}$ and Calindol are potent arterial relaxants [18, 34]. The study also suggested that vasodilators play a major role in modulating the proliferation of VSMCs in diabetic models [5]. Some studies have shown that $\mathrm{H}_{2} \mathrm{~S}$ dilates and hyperpolarizes animal arteries through activation of the $\mathrm{BK}_{\mathrm{Ca}}$ or $\mathrm{K}_{\mathrm{ATP}}$ channels $[35,36]$, while the mechanisms of Calindol have remained poorly understood [37]. In this study, we verified that Calindol (5 $\mu \mathrm{M}$ ) or NaHS $(60 \mu \mathrm{M})$ elicited a relaxation response in isolated rat mesenteric arteries (Fig 3AC), which proved the vasodilator's function and vascular protection of Calindol and exogenous $\mathrm{H}_{2} \mathrm{~S}$. Our data also confirmed that the activation of CaSR and NaHS inhibited the viability and proliferation of VSMCs (Fig 8A, D), and the immunofluorescence of PCNA decreased (Fig 8B) while P21 increased (Fig 8C). These results demonstrated that the activation of CaSR and NaHS inhibited VSMCs proliferation. Furthermore, the expression of CaSR and CSE and the $\mathrm{H}_{2} \mathrm{~S}$ concentration decreased in the diabetic and hyperglycemic conditions (Fig $1 \mathrm{C}$ and Fig $6 \mathrm{~A}-\mathrm{B}, \mathrm{D}$ ), while the CaSR agonist increased the expression and activity of CSE and the $\mathrm{H}_{2} \mathrm{~S}$ concentration in response to hyperglycemia (Fig 6C-E). Furthermore, pretreatment with 2-APB antagonized the effect of CaSR, and the results of VSMCs were in accordance with the protein expression patterns of the diabetic rat mesenteric arteries (Fig 2A-C) and low glucose condition (Fig 4). However, the expression of CaSR was not statistic significance in mesenteric arteries of diabetic rats at 4 weeks, this maybe involved in the experimental cases insufficient or short intervention time because we showed the reduced trend in the experiment (Fig 2A). The expression of CaSR was decreased in 8-12 weeks (Fig 2B-C) and 


\section{Cellular Physiology Cell Physiol Biochem 2015;35:1582-1598 \begin{tabular}{l|l} 
DOI: 10.1159/000373973 & O 2015 S. Karger AG, Basel
\end{tabular} and Biochemistry Published online: March 18, $2015 \quad$ www.karger.com/cpb \\ Zhong et al.: CaSR Regulating VSMCs Proliferation}

in VSMCs with the treatment of CaSR activator or HG (Fig 4 and Fig 6) in vitro. These data suggest that activation of CaSR modulates the $\mathrm{CSE} / \mathrm{H}_{2} \mathrm{~S}$ pathway via the $\mathrm{IP}_{3}$ receptor pathway in response to hyperglycemia. The mechanisms underlying the antiproliferative effect of $\mathrm{H}_{2} \mathrm{~S}$ are multifaceted. A recent study suggested that one of the focal point of these studies is the involvement of the mitogen-activated protein kinase (MAPK) superfamily [31]. Whether the modulation of CaSR on CSE $/ \mathrm{H}_{2} \mathrm{~S}$ pathway, which inhibits VSMC proliferation, is related to the MAPK superfamily needs further study.

A previous study [38] suggested that in adult blood vessels, VSMCs proliferate at an extremely low rate; however, in response to vascular injury, proliferation increases dramatically, and the cells become dedifferentiated owing to their inherent plasticity. Depending on the pathological state, the contractile phenotype of VSMCs can be altered from a quiescent contractile to a proliferative synthetic phenotype [39]. In the present study, we have proved that NaHS inhibited the alteration of VSMC phenotype by Masson's trichrome staining (Fig 7A) and western blot analysis (Fig 7B). These results are in accordance with the ultrastructure alteration of rat mesenteric arteries (Fig 1A-B) and elucidated the biological mechanism through which $\mathrm{H}_{2} \mathrm{~S}$ inhibits the proliferation of VSMCs.

CaSR-mediated $\mathrm{H}_{2} \mathrm{~S}$ generation in VSMCs via $\mathrm{Ca}^{2+}$ signaling may serve as a common pathway in regulating the proliferation of VSMCs. If so, activation of $\mathrm{Ca}^{2+}$ release from the ER through CaSR may attenuate VSMCs proliferation in the hyperglycemic condition. The contribution of CaSR-mediated $\mathrm{Ca}^{2+}$ signaling to VSMCs proliferation shown in this study is the first demonstration of an important role for this receptor in diabetes.

\section{Conclusions}

The current study is the first to demonstrate an important role for CaSR in $\mathrm{Ca}^{2+}$ signaling, which is involved in VSMCs proliferation, and this role is mediated by the PLCIP3 receptor pathway and initiated by $\mathrm{CSE} / \mathrm{H}_{2} \mathrm{~S}$ pathway. Our study opens a new avenue to explore the potential roles of $\mathrm{Ca}^{2+}$ signaling in regulating VSMCs proliferation and could lead to the development of more effective approaches for treating VSMCs proliferation in diabetic vessels.

\section{Disclosure Statement}

The authors declare that they have no conflict of interest.

\section{Acknowledgements}

This work was supported by National Natural Science Foundation of China (No.81170289, 81170218, 81370421, 81370330, 81300164, 81170178), the Heilongjiang Provincial Nature Science Foundation (No.H201401) and the Heilongjiang Postdoctoral fund (No.LBH-Z13149) and the Key Laboratory of Cardiovascular Medicine Research (Harbin Medical University), Ministry of Education, No.2013007 for Xin Zhong.

\section{Reference}

1 Hong SJ, Kim ST, Kim TJ, Kim EO, Ahn CM, Park JH, Kim JS, Lee KM, Lim DS: Cellular and Molecular Changes Associated With Inhibitory Effect of Pioglitazone on Neointimal Growth in Patients With Type 2 Diabetes After Zotarolimus-Eluting Stent Implantation. Arterioscler Thromb Vasc Biol 2010;30:2655-2665.

2 Planas-Silva MD, Weinberg RA: The restriction point and control of cell proliferation. Curr Opin Cell Biol 1997;9:768-772. 


\section{Cellular Physiology Cell Physiol Biochem 2015;35:1582-1598 \begin{tabular}{ll|l} 
and Biochemistry & $\begin{array}{l}\text { DOI: 10.1159/000373973 } \\
\text { Published online: March 18, } 2015\end{array}$ & $\begin{array}{l}\text { O 2015 S. Karger AG, Basel } \\
\text { www.karger.com/cpb }\end{array}$ \\
\cline { 2 - 3 } & zhong
\end{tabular}}

3 Zhang X, Liu L, Chen C, Chi YL, Yang XQ, Xu Y, Li XT, Guo SL, Xiong SH, Shen MR, Sun Y, Zhang CS, Hu KM: Interferon regulatory factor-1 together with reactive oxygen species promotes the acceleration of cell cycle progression by up-regulating the cyclin E and CDK2 genes during high glucose-induced proliferation of vascular smooth muscle cells. Cardiovasc Diabetol 2013;12:147.

4 Grant MB, Wargovich TJ, Ellis EA, Caballero S, Mansour M, Pepine CJ: Localization of insulin-like growth factor I and inhibition of coronary smooth muscle cell growth by somatostatin analogues in human coronary smooth muscle cells. A potential treatment for restenosis? Circulation 1994;89:1511-1517.

5 Gueguen M, Keuylian Z, Mateo V, Mougenot N, Lompre AM, Michel JB, Meilhac O, Lipskaia L, Limon I: Implication of adenylyl cyclase in pathological smooth muscle cell migration occurring in rat and human vascular remodeling. J Pathol 2010;221:331-342.

6 Whiteman M, Armstrong JS, Chu SH, Siau JL, Wong BS, Cheung NS, Halliwell B, Moore PK: The novel neuromodulator hydrogen sulfide: an endogenous peroxynitrite 'scavenger'? J Neurochem 2004;90:765768.

7 Jha S, Calvert JW, Duranski MR, Ramachandran A, Lefer DJ: Hydrogen sulfide attenuates hepatic ischemiareperfusion injury: Role of antioxidant and antiapoptotic signaling. Am J Physiol Heart Circ Physiol 2008;295:H801-H806.

8 Yang G, Wu L, Jiang B, Yang W, Qi J, Cao K, Meng Q, Mustafa AK, Mu W, Zhang S, Snyder SH, Wang R: $\mathrm{H}_{2} \mathrm{~S}$ as a physiologic vasorelaxant: hypertension in mice with deletion of cystathionine gamma-lyase. Science 2008;322:587-590.

9 Zhuo Y, Chen PF, Zhang AZ, Zhong H, Cheng CQ, Zhu YZ: Cardioprotective effect of hydrogen sulfide in ischemic reperfusion experimental rats and its influence on expression of survivin gene. Biol Pharm Bull 2009;32:1406-1410.

10 Yang G, Wu L, Bryan S, Khaper N, Mani S, Wang R: Cystathionine gamma-lyase deficiency and overproliferation of smooth muscle cells. Cardiovasc Res 2010;86:487-495.

11 Zhong G, Chen F, Cheng Y, Tang C, Du J: The role of hydrogen sulfide generation in the pathogenesis of hypertension in rats induced by inhibition of nitric oxide synthase. J Hypertension 2003;21:1879-1885.

12 Zhang C, Du J, Bu D, Yan H, Tang X, Tang C: The regulatory effect of hydrogen sulfide on hypoxic pulmonary hypertension in rats. Biochem Biophys Res Commun 2003;302:810-816.

13 Xiaohui L, Junbao D, Lin S, Jian L, Xiuying T, Jianguang Q Bing W, Hongfang J, Chaoshu T: Down-regulation of endogenous hydrogen sulfide pathway in pulmonary hypertension and pulmonary vascular structural remodeling induced by high pulmonary blood flow in rats. Circ J 2005;69:1418-1424.

14 Brown EM, MacLeod RJ: Extracellular calcium sensing and extracellular calcium signaling. Physiol Rev 2001;81:239-297.

15 Hofer AM and Brown EM: Extracellular calcium sensing and signaling. Nat Rev Mol Cell Biol 2003;4:530538.

16 Smajilovic S, Hansen JL, Christoffersen TE, Lewin E, Sheikh SP, Terwilliger EF, Brown EM, Haunso S, T feltHansen J: Extracellular calcium sensing in rat aortic vascular smooth muscle cells. Biochem Biophys Res Commun 2006;348:1215-1223.

17 Thakore $\mathrm{P}$ and Ho WS: Vascular actions of calcimimetics: role of $\mathrm{Ca}^{2+}$-sensing receptors versus $\mathrm{Ca}^{2+}$ influx through L-type $\mathrm{Ca}^{2+}$ channels. Brit J Pharmacol 2011;162:749-762.

18 Weston AH, Absi M, Ward DT, Ohanian J, Dodd RH, Dauban P, Petrel C, Ruat M, Edwards G: Evidence in favor of a calcium-sensing receptor in arterial endothelial cells: studies with Calindol and calhex231. Circ Res 2005;97:391-398.

19 Fu M, Zhang W, Wu L, Yang G, Li H, Wang R: Hydrogen sulfide $\left(\mathrm{H}_{2} \mathrm{~S}\right)$ metabolism in mitochondria and its regulatory role in energy production. Proc Natl Acad Sci USA 2012;1092943-2948.

20 Zhong X, Wang L, Wang Y, Dong S, Leng X, Jia J, Zhao Y, Li H, Zhang X, Xu C, Yang G, Wu L, Wang R, Lu F, Zhang W: Exogenous hydrogen sulfide attenuates diabetic myocardial injury through cardiac mitochondrial protection. Mol Cell Biochem 2012;371:187-198.

21 Uramatsu T, Nishino T, Obata Y, Sato Y, Furusu A, Koji T, Miyazaki T, Kohno S: Involvement of Apoptosis Inhibitor of Macrophages in a Rat Hypertension Model with Nephrosclerosis: Possible Mechanisms of Action of Olmesartan and Azelnidipine. Biol Pharm Bull 2013;36:1271-1277.

22 Cao Q, Zhang L, Yang G, Xu C, Wang R: Butyrate-stimulated $\mathrm{H}_{2} \mathrm{~S}$ production in colon cancer cells. Antioxid Redox Signal 2010;12:1101-1109. 


\section{Cellular Physiology Cell Physiol Biochem 2015;35:1582-1598 \begin{tabular}{|l|l|}
\hline DOI: 10.1159/000373973 & (c) 2015 S. Karger AG, Basel
\end{tabular} \begin{tabular}{l|l} 
and Biochemistry Published online: March 18, 2015 & www.karger.com/cpb
\end{tabular}}

Zhong et al.: CaSR Regulating VSMCs Proliferation

23 Li HZ, Guo J, Gao J, Han LP, Jiang CM, Li HX, Bai SZ, Zhang WH, Li GW, Wang LN, Li H, Zhao YJ, Lin Y, Tian Y, Yang GD, Wang R, Wu LY, Yang BF, Xu CQ: Role of dopamine D2 receptors in ischemia/reperfusion induced apoptosis of cultured neonatal rat cardiomyocytes. J Biomed Sci 2011;18:1-11.

24 Owens GK, Kumar MS, Wamhoff BR: Molecular regulation of vascular smooth muscle cell differentiation in development and disease. Physiol Rev 2004;84:767-801.

25 Orr AW, Hastings NE, Blackman BR, Wamhoff BR: Complex regulation and function of the inflammatory smooth muscle cell phenotype in atherosclerosis. J Vascul Res 2010;47:168-180.

26 Napoli N, Zardi E, Strollo R, Arigliani M, Daverio A, Olearo F, Tosi D, Dicuonzo G, Scarpa F, Pedone C, Tegue Simo HH, Mottini G, Pozzilli P: Increased carotid thickness in subjects with recently-diagnosed diabetes from rural Cameroon. PloS One 2012;7:e41316.

27 Kimura H: Hydrogen sulfide: its production and functions. Exp Physiol 2011;96:833-835.

28 Yang G, Yang W, Wu L, Wang $\mathrm{R}_{2} \mathrm{H}_{2} \mathrm{~S}$, endoplasmic reticulum stress and apoptosis of insulin-secreting beta cells. J Biol Chem 2007;282:16567-16576.

29 Wilkerson MK, Heppner TJ, Bonev AD and Nelson MT: Inositol trisphosphate receptor calcium release is required for cerebral artery smooth muscle cell proliferation. Am J Physiol Heart Circ Physiol 2006;290:H240-H247.

30 Zhang WH, Fu SB, Lu FH, Wu B, Gong DM, Pan ZW, Lv YJ, Zhao YJ, Li QF, Wang R, Yang BF, Xu CQ: Involvement of calcium-sensing receptor in ischemia / reperfusion induced apoptosis in rat cardiomyocytes. Biochem Biophys Res Commun 2006;347:872-881.

31 Wang R: Physiological implications of hydrogen sulfide: a whiff exploration that blossomed. Physiol Rev 2012;92:791-896.

32 Calvert JW, Coetzee WA, Lefer DJ: Novel insights into hydrogen sulfide-mediated cytoprotection. Antioxid Redox Signal 2010;12:1203-1217.

33 Molostvov G, James S, Fletcher S, Bennett J, Lehnert H, Bland R, Zehnder D: Extracellular calcium-sensing receptor is functionally expressed in human artery. Am J Physiol Renal Physiol 2007;293:F946-F955.

34 Sélley E, Kun S, Szijártó IA, Laczy B, Kovács T, Fülöp F, Wittmann I, Molnár GA: Exenatide induces aortic vasodilation increasing hydrogen sulphide, carbon monoxide and nitric oxide production. Cardiovasc Diabetol 2014;13:69.

35 Jackson-Weaver O, Paredes DA, Gonzalez Bosc LV, Walker BR, Kanagy NL: Intermittent hypoxia in rats increases myogenic tone through loss of hydrogen sulfide activation of large-conductance $\mathrm{Ca}^{2+}$-activated potassium channels. Circ Res 2011;108:1439-1447.

36 Leffler CW, Parfenova H, Basuroy S, Jaggar JH, Umstot ES, Fedinec AL: Hydrogen sulfide and cerebral microvascular tone in newborn pigs. Am J Physiol Heart Circ Physiol 2011;300:H440-H447.

37 Awumey EM, Hill SK, Diz DI, Bukoski RD: Cytochrome P-450 metabolites of 2-arachidonoylglycerol play a role in $\mathrm{Ca}^{2+}$-induced relaxation of rat mesenteric arteries. Am J Physiol Heart Circ Physiol 2008;294:H2363-H2370.

38 Owens GK: Regulation of differentiation of vascular smooth muscle cells. Physiol Rev 1995;75:487-517.

39 Campbell GR, Campbell JH, Manderson JA, Horrigan S, Rennick RE: Arterial smooth muscle. A multifunctional mesenchymal cell. Arch Pathol Lab Med 1988;112:977-986. 